Heyningen 1964). There thus exists at least the theoretical possibility of prevention, or delay in maturation, of cataract in some patients, by early diagnosis and scrupulous control of the diabetes.

Some 16,750 patients over 45 have a cataract extracted each year in England and Wales (Sorsby, 1962). If $13 \%$ of these are diabetics, the annual number of operations on diabetics is 2,180 . At least $3 \%$ of all patients having a senile cataract extracted are previously undiscovered diabetics (Table IV). Thus some 440 diabetics will be diagnosed each year in England and Wales on account of cataract alone. Routine urine-testing of all patients with senile cataract, on their first attendance and on as many subsequent occasions as possible, would seem obligatory, together with detailed investigation of any with even a trace of reducing substance in their urine.

\section{Summary}

A review has been made of 1,485 cataract extractions carried out in the Oxford Eye Hospital in the years 1957-62. First operations for senile cataract numbered 1,024, and $110(10.7 \%)$ of these were on diabetics.

Diabetes was found as a result of cataract in $31(28 \%)$ of the 110 diabetics, or $3 \%$ of all patients having a senile cataract extracted.

A total of 454 patients lived within a defined area. Of these, $13 \%$ were diabetics, and $8.8 \%$ previously known diabetics. Extraction of a senile cataract was calculated to be four to six times more frequent in known diabetics than in non-diabetics.

Senile cataract in known diabetics tends to be associated with diabetes of long duration.

The degree of control of diabetes in patients having a cataract extracted was worse than the average in those attending a diabetic clinic.
These findings are briefly discussed in the light of the known peculiarities of glucose metabolism in the lens.

It is a pleasure to thank Mr. J. P. F. Lloyd, Mr. A. C. L. Houlton, Mr. V. B. Purvis, and Dr. A. M. Cooke for permission to study their patients. Thanks are also due to them and to $\mathrm{Mr}$. M. H. Luntz, Dr. T. B. Stephens, Dr. D. Sevel, Miss B. Bullard, Mr. J. M. D. Burns, Dr. E. D. Acheson, and Dr. J. G. Evans for assistance, advice, and criticism.

\section{REFERENCES}

Anthonisen, H. (1936). Acta Ophthal. (Kbh.), 14, 150

Beckett, A. G., and Hobbs, H. E. (1961). Brit. med. f., 2, 1605. Caird, F. I. (1961). Diabetes, 10, 178.

C and Garrett, C. J. (1962). Proc. roy. Soc. Med., 55, 477.

Clegg, J. G. (1920). Trans. ophthal. Soc. U.K., 40, 37.

Dollfus, M. (1954). Bull. Soc. Ophtal. Fr., 67, 62 .

General Registry Office (1954). Census, 1951, England and Wales. County Reports, Oxfordshire and Berkshire. H.M.S.O., London. (1961). Census, 1961, England and Wales. Preliminary Report, Table 2. H.M.S.O., London.

Heinsius, E., and Arndt, G. (1950). Albrecht v. Graefes Arch. Ophthal., $150,555$.

Kato, K., Amaha, E., Hagai, A., and Martin, M. (1960). Acta soc.

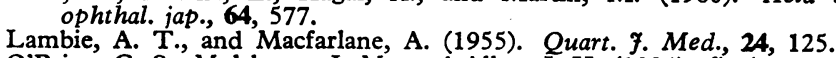

O'Brien, C. S., Molsberry, J. M., and Allen, J. H. (1934). Ұ. Amer. med. Ass., 103, 892.

Parsons, J. (1954). Diseases of the Eye, 12th ed., edited by W. S. DukeElder, p. 264. Churchill, London.

Patterson, J. W. (1951). Amer. F. Physiol., 165, 61.

Pirie, A., and van Heyningen. R. (1964)., Exp. Eye Res., 3

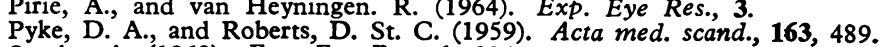
Sorsby, A. (1962). Exp. Eye Res., 1, 296.

Townes, C. D., and Casey, E. R. (1955). Sth. med. F. (Bgham, Ala.), 48, 844.

Tulloch, J. A. (1962). Diabetes Mellitus in the Tropics. Livingstone, Edinburgh.

van Heyningen, R. (1959). Nature (Lond.), 184, 194.

(1962). Exp. Eye Res., 1, 396

Waite, J. H., and Beetham, W. P. (1935). New Engl. f. Med., 212, 367,

Working Party (1962). Brit. med. f., 1, 1497.

\title{
Lymphoma Syndrome in Northern Nigeria
}

\author{
C. G. BERRY,* M.D., D.C.P., M.C.PATH.
}

Brit. med. F., 1964, 2, 668-670

Over recent years the prevalence of a malignant lymphoma in children living in tropical Africa has received much attention. The syndrome described by Burkitt (1958) and by Burkitt and O'Conor (1961) primarily affects non-lymphoid tissues, most commonly presenting as a destructive lesion involving the mandible, maxilla, and face, and may on occasion appear to be multicentric. Burkitt (1962a, 1962b) has observed that in certain parts of tropical Africa this is the commonest malignant tumour of childhood, but that it seems to be limited to areas at an altitude of less than $5,000 \mathrm{ft}$. $(1,524 \mathrm{~m}$.), with a yearly rainfall of more than $20 \mathrm{in}$. $(50.8 \mathrm{~cm}$.), and where the temperature does not fall below $60^{\circ} \mathrm{F} .\left(15.5^{\circ} \mathrm{C}\right.$.) during the coldest season of the year. In fact, this geographic distribution corresponds with that of certain mosquito-borne diseases such as malignant tertian malaria and yellow fever. This observation, along with the apparent multifocal origin of the tumours in some cases, the recognition of the tumour in non-African children living in the areas described, and the age incidence (2-14 years, with a maximum incidence between 5 and 8 years) led to the hypothesis that the tumour might be of virus origin,

* Regional Pathology Laboratory, Kaduna, Northern Nigeria. possibly carried by an arthropod vector. A team from the Virus Research Laboratory, Mill Hill, London, is at present working with the East African Virus Research Institute in Entebbe to investigate this possibility.

Burkitt's tumour is known to occur commonly in those parts of West Africa where the optimal conditions of temperature and humidity apply. Edington and Maclean (1964) have discussed the incidence of the lesion in Ibadan, and earlier accounts of tumours in West Africa include descriptions of what would seem to be the same lesion (Smith and Elmes, 1934 ; Elmes and Baldwin, 1947 ; Edington, 1956). There is no account of the occurrence of Burkitt's tumour in Northern Nigeria, however, although Burkitt (1962c) has stated (from information received from clinicians in Northern Nigeria) that it is virtually non-existent in the northern parts of this region.

\section{Area Covered by Present Survey}

The Northern Region of Nigeria is an area of some 281,800 square miles $(729,860$ sq. km.), extending from Ilorin in the southernmost part of the region, to Sokoto, Kano, and 
Maiduguri in the north. In a territory of such extent there are considerable variations in temperature, rainfall, humidity, and vegetation. In no part does the mean annual rainfall drop below 20 in. $(50.8 \mathrm{~cm}$.), but in the far north most of this falls between the months of June and September. Similarly, even though the humidity may at times reach $75 \%$ in every part of this region, it may well be less than $20 \%$ for six months of each year. These variations are shown in Figs. 1 and 2 .

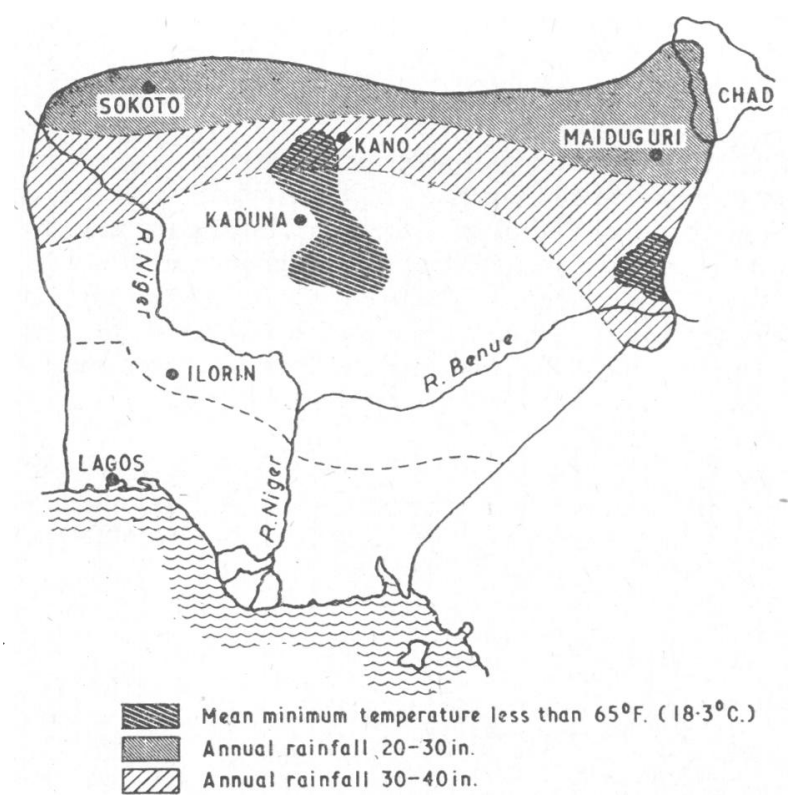

FIG. 1.-Division (--- ) between Northern Region (above) and Western and Eastern Regions (below).

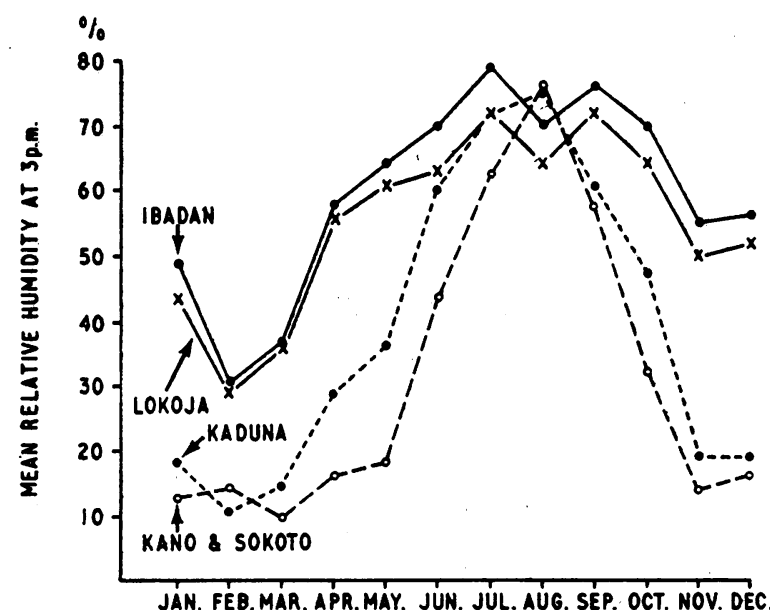

FIG. 2.-Graphs showing mean relative humidity at 3 p.m.

Kaduna is the capital of the Northern Region, and here the Regional Pathology Laboratory accepts specimens for histopathology from both Government and mission hospitals throughout the region. Hospitals in the Kano Medical Area, however (in Kano, Hadejia, Katsina, and Birnin Kudu), generally send tissues for examination to the Kano Pathology Laboratory.

\section{Specimens Examined at the Kaduna Regional Laboratory, 1963-4}

During the year 1963-4 1,170 histology specimens were examined at Kaduna. These were received from 32 Government and 18 mission hospitals. A total of 296 malignant tumours were identified, the most common group being the skin tumours, followed by the malignant lymphomata (see Table I).

Table I.-Malignant Disease (All Age-groups)

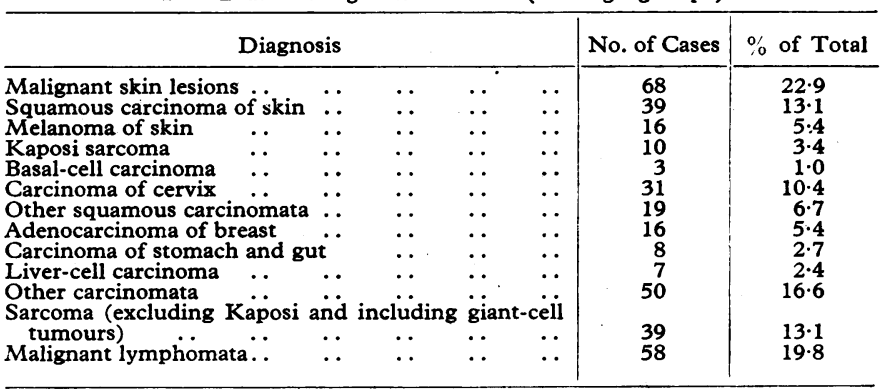

TAble II.-Malignant Disease (0-15 Years)

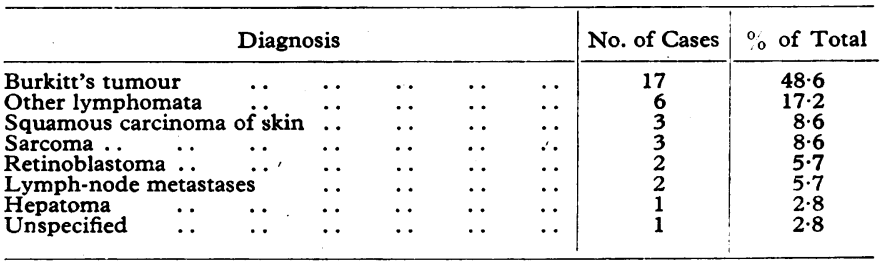

Of these biopsies, 126 were from patients aged $0-15$ years, 35 of these demonstrating malignant neoplasms (Table II). It will be seen that in this age-group malignant lymphoma was by far the most common lesion, and Burkitt's tumour accounted for almost $49 \%$ of all malignancies. With only one exception (Case 457) all showed the characteristic histology of a poorly differentiated lymphocytic lymphoma with scattered histiocytes giving a "starry sky" appearance, described previously by Wright (1963). The exception noted above had the structure of a round-cell sarcoma, with a remarkable cell uniformity, and contained very few histiocytes; this was originally diagnosed as Ewing's sarcoma of bone. Only one case of Burkitt's tumour (No. 1054) was seen outside this age-group ; this presented as an orbital tumour in a youth aged 18. The 18 cases of Burkitt's tumour seen during the year are listed in Table III, with the age and sex of the patients, the site of the tumour, and the hospital from which the specimen was received.

\section{Discussion}

The origin of these specimens of Burkitt's tumour, listed in Table III, is more obviously demonstrated in Fig. 3. It can be seen that there were no cases north of a line joining Garkida, Kaduna, and Kontagora, and that most of the cases came from those areas with a higher temperature, rainfall, and humidity. Although on such a small number of cases it is not possible to reach any general conclusions, the somewhat lower incidence of the Northern Nigerian cases $(50 \%$ of all malignancies of childhood) compared with the Ibadan cases (70\%) and the

TABLE III.-Burkitt's Tumour: Site of Lesions and Origin of Patients

\begin{tabular}{|c|c|c|c|c|}
\hline $\begin{array}{l}\text { Case } \\
\text { No. }\end{array}$ & $\begin{array}{c}\text { Age } \\
\text { (Years) }\end{array}$ & Sex & Site of Tumour & Town of Origin \\
\hline $\begin{array}{r}89 \\
158 \\
321 \\
324 \\
457 \\
477 \\
694 \\
754 \\
772 \\
785 \\
841 \\
856 \\
860 \\
1042 \\
1054 \\
1136 \\
1148 \\
1160\end{array}$ & $\begin{array}{r}4 \\
7 \\
13 \\
8 \\
9 \\
3 \frac{1}{2} \\
13 \\
12 \\
9 \\
4 \\
14 \\
9 \\
10 \\
6 \\
18 \\
7 \\
9 \\
6\end{array}$ & $\begin{array}{c}M \\
M \\
M \\
\text { F } \\
\mathbf{M} \\
\mathbf{M} \\
\mathbf{F} \\
\mathbf{M} \\
\mathbf{M} \\
\mathbf{M} \\
\mathbf{F} \\
\mathbf{F} \\
\mathbf{M} \\
\mathbf{F} \\
\mathbf{M} \\
\mathbf{M} \\
\mathbf{F}\end{array}$ & $\begin{array}{l}\text { Mandible; loosening teeth } \\
\text { Neck tumour, ? salivary } \\
\text { Tumour in scalp } \\
\text { Orbital tumour } \\
\text { Lower end of femur } \\
\text { Mandible } \\
\text { Ovary } \\
\text { Axillary lymph nodes } \\
\text { Gum, around loose teeth } \\
\text { Intestines } \\
\text { Ovary } \\
\text { Ovary } \\
\text { Salivary gland } \\
\text { Tumour of foot } \\
\text { Orbital tumour } \\
\text { Breast and testis } \\
\text { Mandible } \\
\text { Both jaws with loose teeth }\end{array}$ & $\begin{array}{l}\text { Numan } \\
\text { Kontagora } \\
\text { Kaduna } \\
\text { Wukari } \\
\text { Lokoja } \\
\text { Pankshin } \\
\text { Kaduna } \\
\text { Numan } \\
\text { Minna } \\
\text { Kaduna } \\
\text { Mkar } \\
\text { Numan } \\
\text { Bambur } \\
\text { Garkida } \\
\text { Bambur } \\
\text { Garkida } \\
\text { Mkar } \\
\text { Bambur }\end{array}$ \\
\hline
\end{tabular}


preponderance of cases in the southern part of this region, would seem to indicate that the relatively cooler and dryer climate of Northern Nigeria is a less favourable environment for the lymphoma syndrome. However, the apparent incidence of disease in an underdoctored area often depends on the incidence of doctors and on their medical interests. A further analysis of the total biopsy figures in this region during 1963-4 reveals

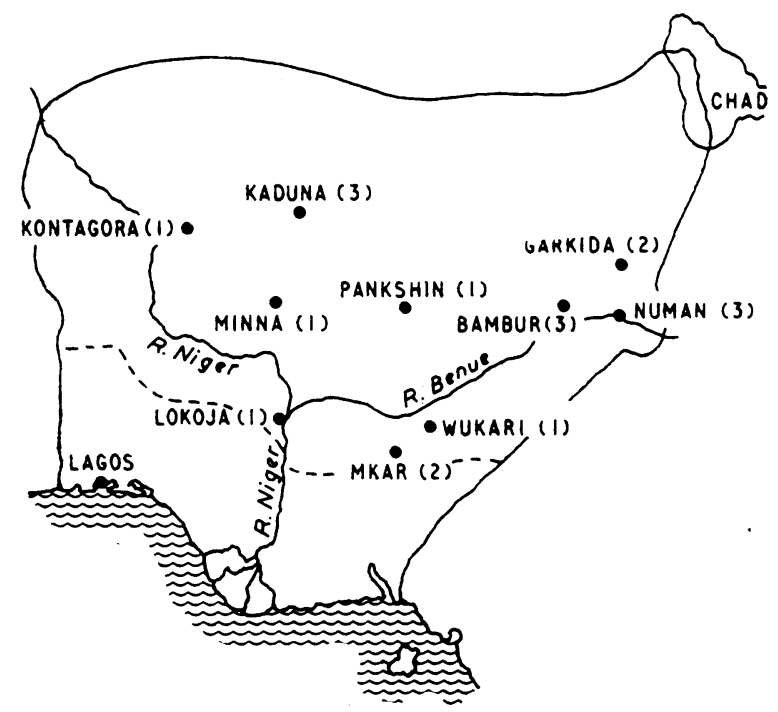

FIG. 3.-Towns from which cases of Burkitt's tumour came.

The number of cases from each town is shown in parentheses.

that 923 specimens were received from hospitals south of the Garkida-Kaduna-Kontagora line, and only 247 were from north of this line. Moreover, of the 126 children on whom biopsy was made, only 23 came from hospitals north of Kaduna.

During the same year 367 biopsies were examined at the Kano Pathology Laboratory. Twenty were from patients of
15 years and under, and 10 of these demonstrated malignant tumours. One, a tumour of jaw in a boy of $3 \frac{1}{2}$ years, was said to be a lymphosarcoma. It seems reasonable to suppose that this could be another case of Burkitt's tumour (F. Vivarelli, personal communication, 1964).

The six other malignant lymphomata of children seen at Kaduna during the year consisted of three lymphosarcomas, two reticulum-cell sarcomas, and one Hodgkin's disease, all involving lymph nodes.

\section{Summary}

The lymphoma syndrome undoubtedly occurs in the Northern Region of Nigeria. Eighteen cases were seen at the Kaduna Regional Pathology Laboratory during the year 1963-4, this representing about $50 \%$ of all malignant tumours of childhood. All the cases came from the southern part of the Northern Region, although one possible additional case was seen at Kano Pathology Laboratory, which receives specimens from the near-by hospitals in the northern part of this region.

I wish to thank the clinicians in the Northern Region of Nigeria for referring specimens to me for examination, and also the Principal Medical Officer in the Northern Nigerian Ministry of Health for permission to publish these cases.

\section{REFERENCES}

Burkitt, D. (1958). Brit. F. Surg., 46, 218. (1962a). Nature (Lond.), 194, 232 (1962b). Ann. roy. Coll. Surg. Engl., 30, 211 (1962c). Brit. med. F., 2, 1019. and O'Conor, G. T. (1961). Cancer, 14, 258.

Edington, G. M. (1956). Brit. F. Cancer, 10, 595.

Ed Maclean, C i U. (1964). Brit. med. 7., 1, 264

Elmes, B. G. T., and Baldwin, R. B. T. (1947). Ann. trop. Med. Parasit. 41, 321 .

Smith, E. C., and Elmes, B. G. T. (1934). Ibid., 28, 461.

Wright, D. H. (1963). Brit. F. Cancer, 17, 50.

\title{
Lincomycin Hydrochloride : Clinical and Laboratory Studies
}

\author{
A. M. GEDDES,* M.B., M.R.C.P.ED. ; R. A. SLEET, $\dagger$ M.B., CH.B. ; J. MCC. MURDOCH, $\ddagger$ F.R.C.P.ED., M.R.C.P.GLASG.
}

Brit. med. 7., 1964, 2, 670-672

Lincomycin was isolated from Streptomyces lincolnensis in 1955 and later described by Mason et al. (1962). The hydrochloride is a white crystalline solid with an empirical formula of $\mathrm{C}_{18} \mathrm{H}_{34} \mathrm{~N}_{2} \mathrm{O}_{6}$ S. $\mathrm{HCl} . \frac{1}{2} \mathrm{H}_{2} \mathrm{O}$ and when stored at $70^{\circ} \mathrm{C}$. for six months shows no detectable degradation. It is very soluble in water and soluble in methanol and ethanol (Herr and Bergy, 1962). In vitro the antibiotic has comparable activity against the same range of Gram-positive organisms as erythromycin (Lewis et al., 1962).

Bacterial resistance to lincomycin develops slowly in vitro (Lewis et al., 1962) and lack of cross-resistance with other antibiotics has been reported from the United States (Mason et al., 1962 ; Walters et al., 1963 ; Clapper et al., 1964). Recent work in the United Kingdom, however, indicates the possibility of dissociated cross-resistance with the macrolides (Barber and Waterworth, 1964).

\footnotetext{
* Senior Registrar, Infectious Diseases Unit, City Hospital, Edinburgh. + Former Registrar, Infectious Diseases Unit, City Hospital, Edinburgh. ‡ Consultant Physician, Infectious Diseases Unit, City Hospital, Edin-
} burgh.
The absorption and excretion characteristics of lincomycin have already been reported (Ma et al., 1963 ; Medina et al., 1963 ; Vavra et al., 1963). It is acid-stable, and animal experiments have shown that most of an ingested dose had left the stomach within two hours in the fasting state. Food in the stomach, however, delayed absorption by more than an hour (Meyer and Lewis, 1963). Oral doses are well absorbed from the upper small bowel, giving peak serum levels after four hours. Higher and more rapidly attainable peak levels can be achieved by intramuscular injection. Twenty-four-hour excretion studies show a variable recovery from the urine, averaging $13 \%$ of an oral dose, and $33 \%$ recovery from the faeces. The fate of the remainder is unknown. Tissue-level estimations indicate that significant concentrations are present in most body tissues, but not in the cerebrospinal fluid, and that bile may be an important route of excretion.

Particular attention has been drawn to the amounts of lincomycin (1.1-6.6 $\mu \mathrm{g}$. $/ \mathrm{g}$.) found in specimens of bone (Holloway et al., 1963), suggesting that this antibiotic may prove valuable in the treatment of staphylococcal osteomyelitis. 